\title{
Efficacy of Biopesticides against White Grub Leucopholis lepidophora (Blanchard) Infesting Sugarcane
}

\author{
S. B. Birajdar*, P. B. Mohite, U. B. Hole, M. D. Thamidela, \\ O. A. Kavitake, S. S. Kadavkar, S. R. Mande and P. S. Jadhav \\ Department of Entomology, R.C.S.M. College of Agriculture, Kolhapur-416004, M.S., India \\ *Corresponding author
}

The experiment entitled "Efficacy of biopesticides against white grub, Leucopholis lepidophora (Blanchard) infesting sugarcane" was conducted in 2019-20 as pot culture experiment with nine treatments, replicated thrice was conducted by using

Keywords

Leucopholis lepidophora, Metarhizium anisopliae, EPN

Article Info

\section{Accepted:}

12 April 2021

Available Online:

10 May 2021
'Completely Randomized Block Design' in Entomology Section, RCSM College of Agriculture, Kolhapur with the objectives, to study the efficacy of biopesticides available in market for the management of white grub under pot culture and to study combined effect of biopesticides against white grub under pot culture experiment. The treatments for pot culture experiment consisted of Metarhizium anisopliae (Grub Guard), M. anisopliae (NBAIR - Ma4), EPN- H. indica (Grub Nash), EPN- H. indica (Solider), EPN- H. indica (Neema Power), UrvaPinaca, Chlorpyrifos and untreated control. In the pot culture experiment $27.41-82.14$ per cent grub mortality of the white grub was observed at 7 DAT, 15 DAT and 30 DAT. The efficacy of biopesticides against white grub of sugarcane under pot culture experiment revealed that $M$. anisopliae(NBAIR - Ma4) + EPN (Grub Nash) was the most effective in controlling white grub (58.12 per cent). The treatments with EPN (Grub Nash) 37.61 per cent followed by M. anisopliae (Grub Guard) and M. anisopliae (NBAIR - Ma4) were next in order of efficacy. Treatment UrvaPinaca found to be least effective against white grub control. The next safe insecticide was Chlorpyrifos.

\section{Introduction}

Sugarcane, Saccharum officinarum (L.) is one of the most important commercial crop belonging to the family Gramineae. Sugarcane is the main source of sugar in the world. Where as sugarcane contributes nearly about 80 per cent of world's total sugar production. India ranks second in the area as well as production of sugarcane next to Brazil. Maharashtra also ranks second in the area and production of sugarcane after Uttar Pradesh (Sugar Industry of India 2018-19).

Up till now 228 insect pest have been reported on the sugarcane crop. About 125 species of insects are known to infest the sugarcane as major pest in various part of world (Rathour et 
al., 2015). Economical loss in sugarcane of about 20 per cent cane yield and 15 per cent in sugar recovery due to insect pest has been estimated. Among these Coleoptera (Scarabaeidae) are the dominant group of soil pests associated with sugarcane. Among them white grub has become most important polyphagous pest causing serious damage (Bharathi and Mohite, 2014)

EPNs have been studied extensively for the control of white grub. Among the two entomopathogenic nematodes, S. glaseri and $H$. indica tested on different instar of white grub (Rathour et al., 2015).

The entomopathogenic fungi have been reported and among these, Metarhizium anisopliae can be effectively utilized one of the components in the management of white grub. However, as not much work has been reported on effectiveness of different EPN, EPF and their combination under laboratory the management is done by using market biopesticides in order to check their efficacy against white grub.

\section{Materials and Methods}

\section{Experiment Details}

\section{Pot Culture Studies}

Crop : Sugarcane

Cultivar : Co 86032

Design : Completely Randomised Block Design (CRBD)

No. of Treatments : Nine

No. of Replications : Three

For pot culture experiment the supply of same instar grubs was essential, hence field survey was conducted around endemic pockets of Kolhapur region to collect grubs, $L$. lepidophora, immediately after the collection of grubs, they were placed in a sterile plastic vials from the same collection site and brought them to the Entomology section.

\section{Procedure}

In Pot culture experiment the $30 \mathrm{ml}$ suspension of each biopesticide prepared according to recommended doses of concentration. The methodology for pot culture experiment was under taken as per the method suggested by Shewale and Mohite, (2014). The grubs were dipped in $30 \mathrm{ml}$ suspension of each formulation for $5 \mathrm{sec}$. Treated individual larvae were transferred separately in to earthen pots. The sugarcane saplings were provided as food.

A set of 10 larvae with three replications for each treatment formulation and control treated with distilled water was maintained.

The experiment was carried out in completely randomized block design (CRBD) with three replications and nine treatments. Eight treatments for grubs in pot were carried out whereas ninth treatment was control. Ten grubs of uniform size were used for each treatment considered as one replicate.

Biopesticides, purchase from local market. The material pot, soil, measuring cylinder, beaker, white grubs was collected from Entomology Section, RCSM College of Agriculture, Kolhapur.

\section{Method of recording observations for pot culture experiment}

The grub mortality was recorded at the interval of 7,15 and 30 days after treatment. The per cent mortality was worked out and the data subjected to analysis of variance. 


\section{Statistical analysis}

Data on per cent mortality were corrected by Abbott's formula (Abbott, 1925) as follows.

Corrected mortality $\mathrm{T}-\mathrm{C}$

$=-----\mathrm{X} 100$

$100-\mathrm{C}$

Where,

$\mathrm{T}=$ Per cent mortality in treatment.

$\mathrm{C}=$ Per cent mortality in control.

Data on corrected grub mortality in pot culture experiments were subjected to arcsine transformations, these transformed data were subjected to analysis of variance.

\section{Results and Discussion}

The overall performance of the treatment with M. anisopliae (NBAIR Ma4) + EPN (Grub Nash) was most effective recording 27.41, 64.81 and 82.14 per cent grub mortality when the observation were recorded at 7,15 and 30 DAT and it was found to be significantly superior over all other treatments. The least $3.33,13.33$ and 23.33 per cent grub mortality was recorded in untreated control when observations were recorded at 7, 15 and 30 DAT, respectively.

Three different entomopathogenic fungi viz., M.anisopliae, B. bassiana and B.brongniartii against third instar grub proved pathogenic to
L. lepidophora of white grub (Mane and Mohite, 2014).

The entomopathogenic nematode like $H$. indica and $S$. carpocapsae found effective against second instar grubs of $H$. serrate (Fab.) infesting sugarcane under laboratory bioassay studies was studied by Supekar and Mohite, (2013). Among that they found the EPN, $H$. indica to be the most effective for first, second and third instar grubs, respectively at 5 DAT. Shewale and Mohite, (2018) in pot culture experiment the entomopathogens $H$. indica, $M$. anisopliae and Chemical insecticides tested in combination, against third instar grub, L. lepidophora B. However, M. anisopliae $+H$. indica + Imidacloprid was superior among them.

The grub mortality at 7, 15 and 30 DAT indicated that all the treatments were significantly superior to untreated control in reduction of L. lepidophora grub population. The treatment with $M$. anisopliae (NBAIR Ma4) + EPN (Grub Nash) at the dose of $50 \mathrm{~g}$ $+50 \mathrm{~g}$ per fifteen liters of water recorded $61.67,70.00$ and 83.00 per cent grub mortality at 7, 15 and $30 \mathrm{DAT}$, respectively and it was found to be significantly superior over all the treatments under pot culture experiment. The treatment with EPN (Grub Nash) was next in order of efficacy followed by $M$. anisopliae (NBAIR Ma4) at 7, 15 and 30 DAT. The rest of the treatments showed the more grub mortality than the untreated control. The result obtained from data observed revealed that all the treatments were superior over untreated control. 
Table.1 Treatment details studies for grubs under pot culture experiment

\begin{tabular}{|c|c|c|c|}
\hline Tr.no. & Treatment & Trade name & Source with Address \\
\hline T1 & $\begin{array}{l}\text { Metarhizium anisopliae } \\
\text { (1.15 WP) }\end{array}$ & Grub Guard & $\begin{array}{c}\text { Natural Care Fertilizers } \\
\text { Gokulam Enterprises No.36, Sri Ram } \\
\text { Nagar, Pondy-Cuddaiore Road } \\
\text { Kanniakoil, Pondicherry } 607402\end{array}$ \\
\hline $\mathbf{T} 2$ & $\begin{array}{c}\text { Metarhizium anisopliae } \\
\text { (1.15 WP) }\end{array}$ & NBAIR - Ma4 & NBAIR \\
\hline T3 & $\begin{array}{c}\text { EPN } \\
\text { (Heterorhabditis indica) } \\
(1.15 \mathrm{WP})\end{array}$ & Grub Nash & $\begin{array}{c}\text { KhandelwalBiofertilizers } \\
\text { Gat No. 21/N/9, Opp.Karnataka } \\
\text { Process, Ichalkaranji-Borgaon Road, } \\
\text { A/P. BorgaonTal.Chikodi, } \\
\text { Dist.Belgavi, Karnataka-591216 }\end{array}$ \\
\hline T4 & $\begin{array}{c}\mathrm{EPN} \\
(\text { Heterorhabditis indica) } \\
(1.15 \mathrm{WP})\end{array}$ & Solider & $\begin{array}{c}\text { Multiplex } \\
1^{\text {st }} \text { Main Road, Mahalakshimi Layout } \\
\text { Extension, Bangalore- } 580\end{array}$ \\
\hline T5 & $\begin{array}{c}\mathrm{EPN} \\
(\text { Heterorhabditis indica }) \\
(1.15 \mathrm{WP})\end{array}$ & Neema Power & $\begin{array}{l}\text { Shri- Biotech, Hyderabad } \\
\text { K N Biosciences India Sy No. 487, } \\
\text { Opp. Hot Spot Restaurant, Behind } \\
\text { SLI Power Engineers, Bachupally, } \\
\text { Qutinbullapur, Hyderabad -500 } 072\end{array}$ \\
\hline T6 & $\begin{array}{c}\text { Metarhizium anisopliae } \\
(1.15 \mathrm{WP})+\mathrm{EPN} \\
\text { (Heterorhabditis indica }) \\
(1.15 \mathrm{WP})\end{array}$ & $\begin{array}{l}\text { NBAIR - Ma4 } \\
+ \text { Grub Nash }\end{array}$ & $\begin{array}{c}\text { Natural Care }+ \text { Khandelwal } \\
\text { Biofertilizers }\end{array}$ \\
\hline T7 & $\begin{array}{c}\text { UrvaPinaca } \\
\text { (Herbal extract SL) }\end{array}$ & UrvaPinaca & $\begin{array}{c}\text { Bharti Greentech } \\
\text { New MFG. License } 17 \text { Bharati Green } \\
\text { Tech, Dist. Satara, Gal No. 629, At. } \\
\text { Sokasan, Tal. Satara, Dist. Satara. }\end{array}$ \\
\hline T8 & $\begin{array}{l}\text { Chlorpyrifos } \\
20 \% \text { EC }\end{array}$ & Dhanvan-20 & $\begin{array}{c}\text { Shubham Agro Agencies Nasia Road, } \\
\text { Indore, Madhya Pradesh. }\end{array}$ \\
\hline T9 & Untreated Control & - & - \\
\hline
\end{tabular}


Table.2 Evaluation of biopesticides individually and in combination against grub, L. lepidophora under pot culture experiment

\begin{tabular}{|c|c|c|c|c|c|c|}
\hline \multirow[t]{2}{*}{$\begin{array}{l}\text { Tr. } \\
\text { No. }\end{array}$} & \multirow[t]{2}{*}{ Treatments } & \multirow{2}{*}{$\begin{array}{l}\text { Dose per } \\
15 \text { liters } \\
(\mathrm{g} / \mathrm{ml})\end{array}$} & \multicolumn{3}{|c|}{$\begin{array}{c}\text { Mean Per cent of grub } \\
\text { mortality }\end{array}$} & \multirow[t]{2}{*}{ Mean } \\
\hline & & & 7 DAT & 15 DAT & $\begin{array}{c}\text { 30 } \\
\text { DAT }\end{array}$ & \\
\hline $\mathbf{1}$ & $\begin{array}{c}\text { M. anisopliae } \\
\text { (Grub Guard } 1.15 \mathrm{WP} \text { ) }\end{array}$ & 100 & $\begin{array}{c}17.04 \\
(24.38)^{*}\end{array}$ & $\begin{array}{c}38.43 \\
(38.31)\end{array}$ & $\begin{array}{c}56.55 \\
(48.76)\end{array}$ & $\begin{array}{c}37.34 \\
(37.15)\end{array}$ \\
\hline 2 & $\begin{array}{c}\text { M. anisopliae } \\
\text { (NBAIR - Ma4 1.15 WP) }\end{array}$ & 100 & $\begin{array}{c}13.70 \\
(21.73)\end{array}$ & $\begin{array}{c}34.72 \\
(36.10)\end{array}$ & $\begin{array}{c}39.29 \\
(38.81)\end{array}$ & $\begin{array}{c}29.24 \\
(32.21)\end{array}$ \\
\hline 3 & $\begin{array}{c}\text { EPN - H. indica (Grub Nash } \\
1.15 \mathrm{WP})\end{array}$ & 100 & $\begin{array}{c}13.70 \\
(21.73)\end{array}$ & $\begin{array}{c}42.59 \\
(40.74)\end{array}$ & $\begin{array}{c}56.55 \\
(48.76)\end{array}$ & $\begin{array}{c}37.61 \\
(37.08)\end{array}$ \\
\hline 4 & $\begin{array}{c}\text { EPN - H. indica (Solider } 1.15 \\
\text { WP) }\end{array}$ & 100 & $\begin{array}{c}10.37 \\
(18.79)\end{array}$ & $\begin{array}{c}31.02 \\
(33.84)\end{array}$ & $\begin{array}{c}39.29 \\
(38.81)\end{array}$ & $\begin{array}{c}26.89 \\
(30.48)\end{array}$ \\
\hline 5 & $\begin{array}{c}\text { EPN - H. indica (Neema Power } \\
1.15 \text { WP) }\end{array}$ & 100 & $\begin{array}{c}10.37 \\
(18.79)\end{array}$ & $\begin{array}{c}26.85 \\
(31.21)\end{array}$ & $\begin{array}{c}30.36 \\
(33.43)\end{array}$ & $\begin{array}{c}22.53 \\
(27.80)\end{array}$ \\
\hline 6 & $\begin{array}{c}\text { M. anisopliae } \\
\text { (NBAIR }- \text { Ma4 } 1.15 \text { WP })+ \\
\text { EPN - H. indica }(\text { Grub Nash } \\
1.15 \text { WP) }\end{array}$ & $50+50$ & $\begin{array}{c}27.41 \\
(31.57)\end{array}$ & $\begin{array}{c}64.81 \\
(53.62)\end{array}$ & $\begin{array}{c}82.14 \\
(65.00)\end{array}$ & $\begin{array}{c}58.12 \\
(50.06)\end{array}$ \\
\hline 7 & UrvaPinaca & 100 & $\begin{array}{c}6.67 \\
(14.96)\end{array}$ & $\begin{array}{c}18.98 \\
(25.83)\end{array}$ & $\begin{array}{c}26.19 \\
(30.78)\end{array}$ & $\begin{array}{c}17.28 \\
(23.86)\end{array}$ \\
\hline 8 & Chlorpyrifos & 40 & $\begin{array}{c}10 \\
(18.43)\end{array}$ & $\begin{array}{c}26.39 \\
(30.91)\end{array}$ & $\begin{array}{c}29.76 \\
(33.06)\end{array}$ & $\begin{array}{c}22.05 \\
(27.47)\end{array}$ \\
\hline 9 & Untreated Control & - & $\begin{array}{c}3.33 \\
(10.52)\end{array}$ & $\begin{array}{c}13.33 \\
(21.42)\end{array}$ & $\begin{array}{c}23.33 \\
(28.88)\end{array}$ & $\begin{array}{c}13.33 \\
(20.27)\end{array}$ \\
\hline & S.Em \pm & & 4.20 & 3.09 & 2.65 & \\
\hline & CD $(5 \%)$ & & 12.49 & 9.20 & 7.90 & \\
\hline & CV & & 3.86 & 1.55 & 1.13 & \\
\hline
\end{tabular}

DAT=Days after treatment; *Figures in parenthesis are arcsine transformed value

\section{References}

Abbott, W. S., 1925. A method of computing effectiveness of an insecticide. J. Econ. Entomol. 18:265-267.

Bharathi, S. and Mohite, P. B., 2015. Biocontrol potential of entomopathogenic nematodes Heterorhabditis and Steinernema against second instar grub of white grub, Leucopholis lepidophora (Blanchard). International Journal of Science and Research.4(10):23197064.
Douressamy, S., V. Ravichandran and J. Jayakumar., 2018. Field efficacy of insecticides and bioinoculants against white grub in sugarcane. Ann.Pl.Protec.Sci.26(2): 287-290.

Rathour, B., Mohite, P. B. and Gite, R. B., 2015. Bioefficacy of entomopathogenic nematode, Steinernema carpocapsae against white grub, Phyllognathus dionysius (Feb). under laboratory condition. J. Of Global Bioscience. 4 (8): 3165-3170.

Shewale C. P. and Mohite P. B., 2018. Combined efficacy of 
entomopathogens and insecticides against white grub, Leucopholis lepidophora (Blanchard) infesting sugarcane. M.Sc. Thesis from Mahatma Phule Agricultural University, Rahuri, Maharashtra, India. Sugar Industry of India 2018-19 Report.
Biocontrol potential of entomopathogenic nematodes. Heterorhabditis and Steinernema against second instar grub of white grub, Holotrichia serrata (Fab) infesting sugarcane. Journal of Global Bioscience ISSN 2320-1355. (2) 24372439.

Supekar, S. and Mohite, P. B., 2013.

\section{How to cite this article:}

Birajdar, S. B., P. B. Mohite, U. B. Hole, M. D. Thamidela, O. A. Kavitake, S. S. Kadavkar, S. R. Mande and Jadhav, P. S. 2021. Efficacy of Biopesticides against White Grub Leucopholis lepidophora (Blanchard) Infesting Sugarcane. Int.J.Curr.Microbiol.App.Sci. 10(05): 203-208. doi: https://doi.org/10.20546/ijcmas.2021.1005.027 